\title{
Building Party Brands in Argentina and Brazil ${ }^{1}$
}

\author{
Noam Lupu
}

Successful mass parties need to build a stable base of partisans, citizens who feel an affinity with the party. Around the world, voters are much more likely to support the party with which they identify (e.g., Campbell et al. 1960; Green, Palmquist, and Schickler 2002; Lupu 2015a). Partisanship also stabilizes elections and protects parties from volatile shifts in public opinion. Even when a party fails to fulfill its campaign promises, or oversees a period of economic decline, partisans are willing to give their party the benefit of the doubt (Kayser and Wlezien 2011). To use Hirschman’s (1970) terms, partisans will support their party out of loyalty. And loyalty "can serve the socially useful purpose of preventing deterioration from becoming cumulative, as it so often does when there is no barrier to exit" (79).

Research on mass partisanship has nevertheless focused little on how partisan attachments emerge. That is partly because studies of partisanship focus largely on established democracies, where parties and partisan attachments are already widespread and stable. ${ }^{2}$ Scholarship about partisanship in these settings typically turns on whether partisan attachments are stable predispositions or instead fleeting attitudes (Bartle and Bellucci 2009; Budge, Crewe, and Farlie 1976). Evidence of partisan stability is thought

\footnotetext{
${ }^{1}$ For their advice and suggestions, I thank the editors, the anonymous reviewers, Fran Hagopian, Henry Hale, and participants at the conference on "Challenges of Party-Building in Latin America" at Harvard. I also thank David Samuels, Cesar Zucco, and the Center for the Study of Public Opinion at the State University of Campinas for generously sharing data. A previous version of this chapter was presented at the 2014 annual meeting of the American Political Science Association. I gratefully acknowledge the support of the Center for Advanced Study in the Social Sciences at the Juan March Institute. Sebastián Lavezzolo provided excellent research assistance. Replication material available on the author's website. ${ }^{2}$ Extrapolating from these cases, Converse (1969) posits that mass partisanship will necessarily emerge over time in new democracies, but leaves unanswered the question of which parties will attract partisans.
} 
to support theories that conceive of partisanship as a social identity (e.g., Green, Palmquist, and Schickler 2002), while evidence of unstable partisanship is thought to support a more rationalistic interpretation of partisanship as a 'running tally' of performance evaluations (e.g., Thomassen 1976). But these studies tell us little about the circumstances under which parties successfully grow their partisan base.

A handful of studies took up the reverse question - why partisanship erodes when, in the 1970s and 1980s, scholars of advanced democracies observed aggregate declines in reported partisan attachments. Most offered structural explanations that emphasized the spread of education, emerging mass media, or public financing of parties (Dalton 1984; Flanagan and Dalton 1984; Inglehart 1977; Katz and Mair 1995; Ward 1993). Yet these arguments found little empirical support in analyses of aggregate and individual-level data (Albright 2009; Arzheimer 2006; Berglund et al. 2006; Huber, Kernell, and Leoni 2005; Schmitt-Beck, Wieck, and Christoph 2006; Schmitt and Holmberg 1995). ${ }^{3}$ More recently, scholars of developing democracies have also begun to grapple with trends of partisan erosion (Lupu 2014, Forthcoming; Morgan 2011; Seawright 2012). But theories of partisan erosion do not necessarily tell us about partisan emergence.

As a result, we still know little about where mass partisanship comes from, a crucial question for understanding how and when party-building succeeds. Developing democracies - where parties are nascent or partisan attachments weakened by authoritarian interludes - offer opportunities for studying how partisanship emerges. In

\footnotetext{
${ }^{3}$ Even the observation of partisan erosion in these countries has been contested (Bartels 2000; Green, Palquist, and Schickler 2002; Hetherington 2001; Schmitt and Holmberg 1995).
} 
these settings, some new parties successfully cultivate mass attachments whereas others do not. How do we explain these divergent outcomes?

I argue that one important determinant of whether new parties succeed in building a partisan base is their ability to develop a strong and broad-based party brand (see Lupu 2014, Forthcoming). Party brands give voters an idea of the type of citizen a particular party represents. When parties offer a demonstrably consistent brand that appeals to a substantial swath of the electorate, voters attracted to that brand are more likely to form lasting attachments. When parties are inconsistent, constantly shifting positions, such attachments are unlikely to form. At the same time, partisanship also depends upon voters' ability to distinguish among competing parties. If the differences between the parties are trivial, voters will fail to form strong attachments to one party over another. Voters will form attachments to a party when they see important differences between their party and its competitors.

Branding alone does not ensure that citizens form lasting partisan attachments; parties must also make themselves known to a citizenry that may have little experience with parties and often pays little attention to politics (Brader and Tucker 2008; Delli Carpini and Keeter 1996). Often, parties need a presence in local communities to become a salient category of identification for voters (Samuels and Zucco Forthcoming, this volume). But a strong party brand is a necessary condition - even if not, on its own, a sufficient one - for party success (Levitsky et al., this volume).

This chapter argues that branding helps to account for the emergence - and, in one case, decline - of partisan attachments with new parties in Argentina and Brazil. In Argentina, the Front for a Country in Solidarity (FREPASO) emerged in 1994 and 
successfully developed a leftist brand in opposition, one that it subsequently diluted when its coalition government pursued neoliberal policies. As a result, attachments with FREPASO grew in the late 1990s and plummeted during the early 2000s. During the 1990s, Brazil’s Workers’ Party (PT) gradually adopted a more broad-based, moderate leftist brand and benefited from the rightward shift of its main rival. As a result, its partisan base grew throughout this period. Despite vast differences between the two party systems, party brands appear to have played a critical role in building the partisan bases that helped determine the electoral fortunes of these new parties. ${ }^{4}$ Analyses of survey data from Brazil further corroborate the underlying expectation that individuals who perceive differences between the parties are more likely to form partisan attachments.

\section{Party Brands and Mass Partisanship}

Scholars disagree about whether partisanship is a psychological attachment and social identity (e.g., Campbell 1960; Green, Palmquist, and Schickler 2002) or a product of voters maximizing their expected utilities (e.g., Achen 1992; Fiorina 1981). Empirically, much of the debate between these contrasting perspectives - especially among comparative scholars - has focused largely on the question of partisan stability over time (Bartle and Bellucci 2009; Budge, Crewe, and Farlie 1976). Evidence that partisanship is stable over time is taken to support the social-identity perspective (e.g., Green, Palquist, and Schickler 2002), that partisanship is an "unmoved mover.”

\footnotetext{
${ }^{4}$ Van Dyck (this volume) also studies the diverging eventual fates of FREPASO and the PT. I am primarily interested in the similar ways these parties successfully built partisan bases, though an implication is that the same factor - party brand strength - may help to explain FREPASO's demise.
} 
Conversely, evidence of partisan volatility is considered inconsistent with such theories (e.g., Thomassen 1976). The underlying logic is that while voters' evaluations of party performance fluctuate from year to year, social identities form in childhood or adolescence - whether by socialization or learning - and stabilize thereafter.

Yet, the implication that partisanship must be stable if it is a social identity assumes that the objects of identity (i.e., parties) are themselves stable. The possibility that parties are themselves moving parts is rarely noted. This gap is no doubt partly the result of the overwhelming empirical focus of partisanship research on advanced democracies, the US in particular. In these contexts, the same parties tend to persist and their reputations are slow to change (e.g., Baumer and Gold 1995). But in developing democracies, political parties are often new and may undergo dramatic transformations. In these contexts, the implications of existing theories of partisanship are not immediately apparent. What can they tell us about the rise and decline of mass partisanship in developing democracies? Answering this question requires building upon existing theories about the origins of mass partisanship.

We can think of party attachments as group identities, akin to the attachments people form to social groups. ${ }^{5}$ They are based on the stereotypes people have about each group (see Baumer and Gold 1995; Green, Palmquist, and Schickler 2002; Rahn 1993; Sanders 1988). People have an idea about what the prototypical poor person looks like, or how the prototypical banker behaves, and they categorize themselves into group identities by comparing themselves to the group prototype. Individuals identify as a poor

\footnotetext{
${ }^{5}$ For a formal statement of my argument, see Lupu (2013). I present my theory in social-identity terms, though a similar model could be written from the rationalistic perspective (e.g., Grynaviski 2010). My aim here is not to adjudicate among these perspectives.
} 
person or a banker if they think they resemble, or fit, that prototype (Hogg et al. 1995;

Turner et al. 1987). And they also feel closest to a group when they think other groups' prototypes look very different from them, a concept social psychologists call comparative fit (Hogg et al. 2004; Turner 1999).

As with other social identities, a voter feels closest to the party whose prototype she thinks she most resembles, relative to all other parties. Voters form perceptions of party prototypes based on what the parties say and do over time. ${ }^{6}$ Party elites may profess their support for a particular set of policies, they may pass certain legislation, or they may associate themselves with well-known individuals who suggest what kind of voter they represent. As Przeworski and Sprague highlight, "parties appeal to the middle classes, women, or ecologists by presenting themselves as representatives of their interests and values, by evoking appropriate symbols, and by offering specific policy proposals” (1986: 82). Voters thus learn what to associate with the prototypical partisan by observing what politicians say and do. So the prototypical Democrat might be seen as a worker if the Democratic Party is perceived to be the party that looks out for labor interests. These prototypes comprise what I call a party brand. Voters constantly update their perceptions of parties’ brands, incorporating new observations into their prior beliefs about the parties.

Perceptions of party prototypes are necessarily noisy, so we can characterize party brands as weak or strong depending on how precisely voters can pinpoint them. When voters see a party sending clear signals, they develop a clearer image of its prototypical

\footnotetext{
${ }^{6}$ Of course, we never observe other people's vote choices, so citizens rely on other heuristics, including the actions of party elites, to determine what kind of voter a party serves. The party whose elites regularly meet with African American interest groups, march in civil-rights protests, and support policies considered to benefit the African American community, is also more likely to be seen as the party of African Americans.
} 
partisan, and the brand becomes stronger. As their uncertainty about the party's position increases, the party appears to be more heterogeneous, perhaps containing multiple prototypes, and the brand becomes diluted.

These learned party brands form the basis of voters' attachments. A voter will feel the greatest affinity with the party whose prototypical partisan she thinks she most resembles, relative to all other parties. As with other social identities, partisan identity is determined partly by the resemblance, or fit, between the voter's self-image and her image of the party prototype. Party attachments, therefore, increase as voters perceive they more closely fit with the party. The more strongly a voter identifies as a worker, the more strongly she will identify with the party whose prototype is the worker. But when voters are uncertain about what a party's prototype really is - when it is unclear whether a party really looks out for us unionized workers - the less certain they will be about their resemblance to the prototype and the weaker their attachments will be.

These attachments also depend on comparative fit, the degree to which a voter feels she resembles the prototype of one group and differs from that of another group. As Kirchheimer (1966: 192) noted, "There is need for enough brand differentiation to make the article plainly recognizable, but the degree of differentiation must never be so great as to make the potential customer fear he will be out on a limb.” Thus, a voter feels most attached to a party when its prototype most resembles her and the prototypes of other parties seem very different. The worker identifies with the party for labor most when it is also clear that rival parties look out for opposing constituencies, like business owners.

Conceiving of mass partisanship in this way implies that the behaviors of parties can affect voter attachments (Lupu 2013). In particular, parties can build their brands 
through consistency and differentiation. ${ }^{7}$ When disciplined party elites present a consistent message, voters become increasingly certain about the party brand. Similarly, a party that maintains consistent positions from year to year increases citizens' certainty about its brand. Voters that are attracted to that brand will be more likely to identify with the party the more certain they are about what that brand really is. The more Democratic elites consistently seem to represent the interests of workers, the more certain voters will be in their perception of the Democratic prototype as a worker. Greater certainty means that workers will be more likely to identify as Democrats.

Parties must also differentiate themselves from prominent rivals in order to build a strong brand and attract partisans. They may offer very different policies from their opponents, or they may clearly demonstrate their opposition to the positions of rival parties. As they do, voters come to realize that the parties represent very different constituencies, and they become more likely to identify with the one they most resemble. ${ }^{8}$ Even when voters are certain about two party brands, they will form stronger bonds with one over the other if they perceive substantial differences between them. It is not enough for Democratic elites to consistently look out for labor interests to attract workers; it must also be the case that Republican elites consistently seem to look out for business interests.

\footnotetext{
${ }^{7}$ Elsewhere (Lupu 2014, Forthcoming), I examine what this theory of partisanship tells us about the kinds of party behaviors that dilute party brands, erode partisanship, and lead established parties to break down. Here, I study the reverse phenomenon: what kinds of party behaviors strengthen party brands, grow and sustain mass partisanship, and bolster new parties. As I note below, reversing the implications highlights the fact that in order for new parties to build nationally successful brands, they need to be consistent and differentiated, but also broadly appealing.

${ }^{8}$ This may be why more successful parties tend to form in opposition or in contexts of adversity (LeBas 2011; Van Dyck, this volume), where the distinction between them and the ruling party are most stark.
} 
Partisanship thus emerges when parties are consistent and differentiated, but only among those voters who think they resemble the party prototype. So parties seeking a broad, national base must also appeal to a substantial swath of the electorate. A party may have a strong brand borne of consistency and distinguishing itself from competitors, but if that brand represents a minority of voters, its partisan base will be limited. New parties seeking a broad partisan base must, therefore, develop a broadly appealing, consistent brand that differs from rival party brands.

Doing so does not guarantee party success; grassroots organizations, voter experience, and mass attention are likely also necessary (Brader and Tucker 2008; Samuels and Zucco Forthcoming, this volume). But building a strong and appealing brand is a necessary, if not sufficient, condition for party success (Levitsky et al., this volume). Indeed, cases of failed party-building often falter because they fail to develop clear brands (Eaton, this volume; Levitsky and Zavaleta, this volume). ${ }^{9}$

Through different trajectories, both Argentina's FREPASO and Brazil’s PT achieved such broad-based, strong brands that yielded growing partisan bases. Unlike the PT, however, FREPASO quickly diluted that brand in office, eroding its mass partisanship.

\footnotetext{
${ }^{9}$ Whether maintaining a strong party brand is necessary for the survival of parties once they become more established is a separate question. Indeed, parties that already have strong brands and widespread partisan attachments occasionally choose to dilute those brands for electoral gain (Lupu Forthcoming). The fact that these parties sometimes succeed electorally does not imply that weakening their brand has no impact on their partisan base (Domínguez, this volume).
} 


\section{Building and Diluting the FREPASO Brand in Argentina}

When Argentine president Carlos Menem was elected in 1989, he promised massive wage increases and price controls to stem hyperinflation. As the leader of the Peronist Party (PJ), Menem had the backing of labor unions and poor voters attracted by his commitments to state largesse and social justice. But on taking office, he shocked Argentine voters by instead pursuing a staunchly neoliberal set of economic policies (Campello 2015; Gerchunoff and Torre 1996; Stokes 2001). His first package of economic policies sharply devalued the currency and made deep cuts to government spending. He then set about reversing traditional Peronist commitments by privatizing state-owned companies, defying union demands and antagonizing labor leaders, and pardoning military officers convicted of committing crimes during the 1976-83 dictatorships.

These reversals created divisions within the PJ and two prominent defections. In the first, 20 prominent PJ legislators defected from the PJ in early 1990 in protest over both the neoliberal economic agenda and the military amnesty laws (Abal Medina 2009; Novaro and Palermo 1998). Known as the Group of Eight for their eight leaders, they eventually formed a coalition with small leftist parties that became known as the Broad Front (FG). The second prominent defection was that of Mendoza Senator José Octavio Bordón in September 1994. Bordón had been a vocal critic of Menem’s economic agenda for years, leading an internal opposition faction. But he was eventually sidelined within the party and decided to form a new party, Open Politics for Social Integrity (PAIS).

By the time Menem faced reelection in 1995, the two defector parties had united behind Bordón’s candidacy, forming FREPASO. Bordón criticized not only the manner 
in which Menem's economic reforms were passed and the allegations of corruption surrounding the administration, but also the reforms themselves and the neoliberal economic agenda. Menem's economic successes made him difficult to beat, and he won reelection with nearly 50 percent of the vote. But FREPASO demonstrated it had quickly become a nationally competitive force. ${ }^{10}$

FREPASO had staked out a clear and consistent center-left position and had become the clear alternative to the Menem administration's economic agenda. Although it did not argue for reversing all of Menem's reforms, FREPASO leaders emphasized the social costs of neoliberal policies on unemployment, poverty, and inequality, and promised to work to address them. By March 1996, FREPASO was viewed by a plurality of survey respondents as the party that best represented an alternative to Menem's economic project. ${ }^{11}$

The result was that mass attachments to FREPASO increased significantly. Figure 1 plots the proportion of respondents across various opinion polls between 1994 and 2003 who said they identified with FREPASO. From 1994 to 1997, as FREPASO increased its national prominence and as it staked out a consistent position in opposition to Menem and the PJ, it attracted the adherence of leftist voters. Some of these partisans had previously been supporters of Argentina’s second-largest party, the Radical Party (UCR) (Calvo and Escolar 2005). Nevertheless, FREPASO lacked grassroots organizations beyond the city centers and its leaders viewed this as the party's primary

\footnotetext{
${ }^{10}$ Bordón left FREPASO and returned to the PJ in 1996.

${ }^{11}$ Author's calculations from survey of 505 adult residents of Greater Buenos Aires conducted by Römer \& Associates. The questions asked, "What politician or political party do you think today represents the clearest opposition to the government?"
} 
electoral obstacle (Abal Medina 2009; Van Dyck, this volume). Bordón’s votes in 1995 were concentrated in the urban centers and the party won only three Senate seats.

[Figure 1 here]

The UCR's presidential candidate came in third in 1995, in one of the party's worst electoral defeats in history. For decades, the UCR and PJ had competed fiercely. Whereas the PJ promoted heavy state intervention in the economy and drew its electoral support from the rural poor and urban working classes (Levitsky 2003; Lupu and Stokes 2009; McGuire 1997), the UCR appealed to the upwardly mobile middle classes with promises of labor flexibility and greater market openness (Mora y Araujo 1995). But the UCR had diluted its brand as the alternative to Peronism (Lupu 2014, Forthcoming). In the past, the party had taken centrist or center-right economic positions, proposing some of the very market-oriented policies Menem pursued. In late 1993, UCR leader Raúl Alfonsín signed a pact with Menem calling for a constitutional reform that would allow Menem to seek reelection (García Lema 1994; Grindle 2000: ch. 7; Jones 1996; Negretto 2001).

It was not long before the UCR and FREPASO began exploring the possibility of an electoral alliance. Unlike FREPASO, the UCR had spent decades building an organizational presence in rural provinces. An alliance with the UCR offered FREPASO an instant grassroots organization. But it also meant compromising some of its principles. After all, the UCR was ideologically to the right of FREPASO and had become quite indistinguishable from Peronism. ${ }^{12}$ FREPASO leaders like Carlos “Chacho” Álvarez

\footnotetext{
${ }^{12}$ The University of Salamanca has been conducting surveys of legislators across Latin America since the late 1990s. They ask legislators about their perceptions of the ideological positions of the parties, and these results are instructive. In May-June 1998, legislators on average placed the PJ at 7.8 on a 1-10 left-right scale, the UCR at 7.6, and FREPASO at 4.6.
} 
voiced concern about the effects of a pragmatic alliance on the new party's burgeoning “identity” (Álvarez and Morales Solá 2002: 69).

Still, leaders in both parties were aware that they could not win a three-way presidential contest in 1999. So in August 1997, the UCR and FREPASO formed an alliance to present joint lists in legislative elections that year. The Alliance for Work, Justice, and Education (Alianza) promised to make "corrections" to the economic model, particularly to address social issues and unemployment. In the October election, it garnered a plurality of the votes (though not a plurality of congressional seats), setting the stage for an Alianza presidential victory in 1999 (Cheresky 2003).

Such a victory, though, would require arduous reconciliation between the two parties. In a hard-fought primary battle, the UCR’s Fernando de la Rúa won out, but the parties agreed to make FREPASO leader Álvarez his running mate (Novaro and Palermo 1998). De la Rúa handily won the presidency, but tensions persisted, both within and between the two parties, over their incongruent, if pragmatic, alliance.

Socioeconomic policy had been one of the primary sources of conflict between the UCR and FREPASO on the campaign trail. Meanwhile, financial crises in Asia and Brazil put pressure on the Argentine economy. On taking office, De la Rúa announced tax increases and austerity measures, including cuts in education and social services, the very areas the Alianza had promised to reinforce. ${ }^{13}$ The cuts were deeply criticized by FREPASO legislators and cabinet members. Although the Alianza held a majority in the Chamber of Deputies, the dissent of some of the FREPASO legislators made it difficult

\footnotetext{
13 The justification offered by the administration was that the federal government's fiscal situation was worse than previously thought. Álvarez later argued that, "we were prisoners of the recession and the deficit” (Álvarez and Morales Solá 2002: 105).
} 
for the De la Rúa administration to gain support for its legislative agenda (Jones and Hwang 2005). In a telling sign of the conflicts within the Alianza, De la Rúa resorted to legislating by presidential decree (Mustapic 2005).

De la Rúa also resorted to making decisions without consulting Álvarez or the rest of FREPASO. Throughout 2000, the conflict between the president and vice president became increasingly heated and public. In June, journalists began to uncover evidence that certain senators had been paid bribes by the administration in return for their support of a labor reform bill. Álvarez and FREPASO had spent years accusing the Menem administration of corruption and demanded that the Alianza hold itself to a higher standard. But De la Rúa refused to open investigations, leading Álvarez to announce his resignation. ${ }^{14}$

FREPASO stayed in the Alianza, ${ }^{15}$ but relations with De la Rúa and the UCR were strained beyond repair. In early 2001, De la Rúa appointed a staunch neoliberal as Minister of the Economy and announced new spending cuts to education, a direct contradiction of one of the foundations of FREPASO's program. The reaction from FREPASO was swift. Party leaders spoke out against the administration with unrestrained vehemence. Within weeks, the Radical president decided he could no longer govern with FREPASO and began to rely instead on the architect of Menem's neoliberal reforms, Domingo Cavallo, and his backers in the PJ. By the end of 2001, economic pressures forced De la Rúa to resign the presidency (Levitsky and Murillo 2003).

\footnotetext{
${ }^{14}$ Álvarez's resignation was apparently celebrated within the administration (Novaro 2009: 587). A few months later, Álvarez also resigned from FREPASO.

${ }^{15}$ Would a formal break with the administration have helped FREPASO preserve its brands? A great deal of damage was already done by 2001, so it might have been too late. Moreover, FREPASO had been so critical in getting De la Rúa elected that it is unlikely that a procedural break would have done much to dissociate the two in the minds of Argentines.
} 
Argentines’ attachments to FREPASO declined precipitously during the Alianza administration (see Figure 1). The incongruence of the UCR-FREPASO alliance was not immediately obvious, particularly while the Alianza was in opposition in the final years of Menem's second term. But once in office, it became increasingly clear that FREPASO had allied itself with a party willing to implement the very policies FREPASO emerged to oppose. Forced to make difficult governing decisions, FREPASO abandoned its brand completely. Álvarez had been right to worry about the effects of the alliance on the fledgling party's identity. FREPASO would come to be seen as indistinguishable from the UCR and the PJ; all three seemed to the public to be supporting the same kinds of economic policies. The Alianza administration diluted the brand FREPASO had built in the mid-1990s and Argentines abandoned the party.

\section{Building the PT Brand in Brazil}

Scholars of Latin America long listed Brazil’s party system among the region's weakest and most fragmented (Mainwaring and Scully 1995). Among its perceived flaws, mass partisanship in Brazil appeared to be fairly weak and limited (Mainwaring

1999). But since redemocratization, the Brazilian party system appears to have coalesced in some ways (Hagopian, Gervasoni, and Moraes 2009; Lyne 2005; Power and Zucco 2009), and partisan attachments appear to have become more widespread and more meaningful (Samuels 2006; Samuels and Zucco 2010, 2014, this volume; Sousa Braga and Pimentel 2011).

Most of that development has been driven by the PT, initially a radical socialist party that emerged in the 1970s out of social movements and independent unions (Keck 
1992; Meneguello 1989). Unlike other parties in Brazil, the PT was widely regarded as programmatic, disciplined, and organizationally rooted (Hunter 2010). In an open-list electoral system that fosters candidate-centered voting, the PT promoted the party label and consistently attracted more party-line votes than its competitors (Samuels 2001). ${ }^{16}$ Its leader, Luiz Inácio Lula da Silva, became a recurring contender for president after the transition, and the PT soon emerged as the leading national party of the Brazilian left (Melo and Câmara 2012).

Within a few years of democratiation, presidential elections became races between the PT and its main rival, the Brazilian Social Democratic Party (PSDB). The PSDB splintered from the successor of the military-sanctioned opposition party, the Brazilian Democratic Movement Party (PMDB). Originally conceived as a center-left party like European social-democratic parties, the PSDB shifted decisively to the right during the neoliberal administration of Fernando Henrique Cardoso (1994-2002) (Fernandes Veiga 2011; Power 1998, 2008). Yet, while the PSDB has become the main national rival of the PT (Melo and Câmara 2012), it remains weakly institutionalized as a decentralized coalition of state-level personalities with loose organizational ties and few links to civil society (Roma 2002, 2006).

Whereas the PSDB shifted its ideological position to the right during the 1990s, the PT shifted rightward in the late 1990s and early 2000s. After Lula's second defeat in 1994, the party began to rethink its radical leftist program and perception. Its close association with unions and organized social movements meant that it rarely attracted

\footnotetext{
${ }^{16}$ Hunter (2010: 58) reports that in a 2002 poll, 93 percent of respondents associated the PT or Lula with the number it is assigned in the Brazilian ballot system, whereas less than 1 percent correctly associated other parties with their numbers.
} 
votes from the poor Northeast of the country despite its promises of land reform and redistribution (Hunter 2010). Lula and other party pragmatists pushed the party to moderate its program to attract center-left votes, particularly once that political space was abandoned by the PSDB (Samuels 2004; Ribeiro 2014). Their efforts gained particular momentum after Lula's third defeat in 1998. Even Lula's image got a makeover that entailed "coaching his speech and inducing him to don a suit and tie, crop his beard, lose weight, whiten his teeth, and stop chain-smoking” (Hunter 2010: 111).

By the end of Lula's second term in office, the PT had repositioned itself as a center-left party opposing the center-right platform of the PSDB. Its partisans were now more centrist (Fernandes Veiga 2011) and poorer (Samuels and Zucco 2010), and Lula's support came increasingly from poorer regions (Hunter and Power 2007; Zucco 2008). In 1997, few poor survey respondents viewed the PT as the party that most closely represents their interests. ${ }^{17}$ But by 2006, many more did; in fact, when asked which party most protects them, poor respondents in 2006 were far more likely to choose the PT than any other party. ${ }^{18}$ In 2010, when survey respondents were asked to locate national figures on a 0-10 scale of closeness to the poor, they placed Lula's successor, Dilma Rousseff, closer to the poor and the PSDB's José Serra closer to the rich. ${ }^{19}$

Over the course of the 1990s and 2000s, the shifting positions of the PT and PSDB entailed changes to their brands and, potentially, to their distinctiveness. Since

\footnotetext{
${ }^{17}$ Based on author's calculations from a November 1997 national survey of 2,700 adults conducted by the Fundação Perseu Abramo.

${ }^{18}$ Based on author's calculations from a March 2006 national survey of 2,379 adults conducted by the Fundação Perseu Abramo.

${ }^{19}$ Interestingly, the perceived differences between the parties increased over the course of the 2010 election campaign.
} 
these two parties largely head up the major legislative blocs and regularly contend for the presidency, they are the most prominent parties in Brazilian voters' minds. The PSDB had always held a moderate ideological position, so its shift to the center-right should have altered the makeup of its support base without necessarily increasing it. In fact, such a shift might have weakened the party's brand in the short term by confusing voters (see Lupu 2014, Forthcoming). But the consistently weak institutionalization of the PSDB, its subordination to individual leaders, and its decentralized organization have doubtless helped prevent the party from fostering a strong partisan base, either as a center-left party early on or as a center-right one since the Cardoso presidency.

On the other hand, the PT stood to gain significant partisan appeal from both its own rightward shift and from that of its rival. As Hunter notes, “The party’s ideological moderation brought it closer to the center of the distribution of popular preference,” (Hunter 2010: 38) making the PT brand seem closer to the interests of a larger swath of the electorate. That brand would need to be diluted somewhat to make the party's shift credible; in 2002, for instance, Lula's electoral coalition included a party of the right for the first time. ${ }^{20}$ And any shift in program entails some inconsistency between the party's past promises and its new ones. But the PT maintained its commitment to egalitarian social policies even while it adopted more moderate economic ones (Hunter 2010). It also maintained its deep links to civil society organizations (Amaral 2011; Samuels and Zucco, this volume). Moreover, the PT benefited from its high level of internal discipline

\footnotetext{
${ }^{20}$ Unlike the FREPASO-UCR alliance, the PT's alliances with rightwing parties were far less prominent. Although these alliances were necessary to secure a legislative majority, most Brazilian voters were unaware of the alliances and few recognize these small rightwing parties.
} 
and from the pragmatism of its leaders, which allowed it to stake out a new ideological position without provoking internal conflicts like those experienced by FREPASO.

Party brands become weaker by confusing citizens when parties shift positions. But some shifts may move a party closer to or farther from portions of the electorate. Both proximity and uncertainty matter for partisanship, so some party shifts can generate countervailing individual-level effects. The PT’s rightward shift likely confused some Brazilians about the party's brand and weakened their attachments. But the party's moderation made it more appealing to a broader swath of the Brazilian electorate, who could now see themselves in the party prototype. In the aggregate, the positive effect swamps the negative one. This is no doubt partly because the PT's moderation was relatively slow, deliberate, and characterized by little intraparty conflict, in contrast with the rapid, conflict-ridden shift by FREPASO. ${ }^{21}$

The PT brand was also strengthened by the fact that its rightward shift did not entail completely converging with a rival major party. By the time of the PT shift, the PSDB had already abandoned the center-left. That meant that the PT's moderation did not reduce the differences between these rival parties. By some measures, the overall ideological distance between the PT and the PSDB actually grew somewhat during the 1990s and 2000s (Zucco and Lauderdale 2011), particularly given the time that elapsed between the PSDB's rightward shift under Cardoso and the PT's subsequent moderation

\footnotetext{
${ }^{21}$ Samuels and Zucco (Forthcoming, this volume) attribute the growth of PT partisanship to the party's unique grassroots organizational structure and links with local civil society organizations. In their reading, and following Levitsky et al. (this volume), these organizational attributes provide avenues for citizens to participate in party affairs, in turn generating party attachments. But the mechanism by which grassroots organization generates partisanship may be informational rather than participatory. It may be that grassroots organization and close ties with local civil society help a party successfully reach citizens with credible information about what it stands for. As citizens learn this information, they will start to form attachments to it, as long as it also has a clear and appealing brand.
} 
following his reelection. Other measures reveal little to no overall change in the differences between the two parties (Power 2008; Power and Zucco 2009). Either way, the PT seems to have struck the kind of balance between differentiation and appeal that Kirchheimer encouraged. That meant that the PT developed a strong, moderate brand over the course of the 1990s and 2000s. Along with its other grassroots efforts (e.g., Samuels and Zucco Forthcoming, this volume; Van Dyck 2014), the more widely appealing PT brand made it possible for the party to grow its partisan base.

Aggregate survey data largely corroborate these expectations. Figure 2 plots the proportion of respondents to national Datafolha polls who said they identified with the PT between 1989 and 2011. Attachments to the PT have increased dramatically since 1989. As the ideological distance between the PT and PSDB increased over the course of the 1990s, and even as the PT began to shift its own position, identification with the PT grew significantly. PT partisanship then grew dramatically after 1998, once the PT substantially moderated and staked out a position that appealed to many more Brazilians. The upward trend in PT partisanship suffered somewhat during Lula's first term, perhaps because of the corruption scandal that engulfed the party (Hunter and Power 2007), or alternatively because the PT’s ideological comprises in office somewhat weakened its brand. Still, the overall trend of growing PT partisanship seems to correlate closely with the party's shift to a more appealing brand and its differences with the rival PSDB.

[Figure 2 here]

Interestingly, the PSDB has not similarly benefited - in terms of its partisan base - from its national prominence and consistent ideological differences with the PT. Why this is the case remains an open question. Relative to the PT, the PSDB is far less 
institutionalized, far less disciplined, and far more decentralized, which may mean that its brand seems more ambiguous to voters. Another possibility is that while the PSDB has an equally strong brand, it has not engaged in grassroots efforts to attract partisans, whereas the PT has (Samuels and Zucco, this volume). A strong party brand may be a necessary condition for building a partisan base, but is not on its own sufficient, and the PSDB may be lacking the additional efforts needed to attract partisans.

\section{Party Perceptions and Partisanship: Testing Individual-Level Expectations}

The experiences of FREPASO in Argentina and the PT in Brazil are consistent with the notion that distinguishable party brands are a necessary condition for building partisanship. But the observed correlations between aggregate attachments and party polarization do not tell us whether individuals who perceive the parties to be more polarized are those who form a party attachment. They also cannot confirm whether the relationship between these variables is causal.

Unfortunately, individual-level data from the late 1990s in Argentina is sparse, and I know of no survey that asked voters about their perceptions of party positions. But such data is available for Brazil, where a National Election Study (ESEB) was conducted in 2002, 2006, and 2010. These national surveys asked respondents to place the major Brazilian parties on a 0-10 left-right scale. ${ }^{22}$ I use these responses to construct a measure

\footnotetext{
${ }^{22}$ The surveys asked respondents about 6-9 parties; given Brazil's fragmented party system, this means that some relevant national parties were left out. Specifically, the 2002 survey asked respondents to place the PT, PSDB, Party of the Liberal Front (PFL), PMDB, Brazilian Socialist Party (PSB), Labor Democratic Party (PDT), Brazilian Labor Party (PTB), and Liberal Party (PL). The 2006 survey asked about the PMDB, PT, PSDB, PFL, PDT, PTB, and Socialism and Freedom Party (P-SOL). The 2010 survey asked about the PT, PMDB, PSDB, Republic Party (PR), Democrats (DEM), PSB, Progressive Party (PP), PDT, and PTB. The parties covered represented $86.6 \%$ of the lower-house vote in $2002,64 \%$ in 2006, and $79.6 \%$ in 2010 . This means that my measure of perceived polarization is imperfect, particularly in 2006.
} 
of a respondents' perception of how polarized the party system in her country is. I measure perceived polarization as the mean distance a respondent places between the parties. So, for a respondent who placed five parties on the left-right scale, I take a weighted average of the 20 distances between each pair of parties (see also Lupu 2015b). ${ }^{23}$

If perceiving a distinguishable party brands matters for partisanship, then I should find that respondents who perceive more polarization among Brazil's parties will be more likely to identify with the PT. To test this hypothesis, I analyzed probit models for each survey year that relate perceived polarization with the likelihood of identifying with the PT. These models also control for other individual characteristics that might affect a respondent's propensity to develop a party attachment. We expect that individuals who place themselves close to a party on the left-right scale are more likely to identify with it. I measure an individual's proximity to the PT as the left-right distance between her position and the position she assigns the PT. I also control for demographic characteristics, including education level, household income (except in 2006), age, and gender. $^{24}$

Figure 3 presents the results of this analysis. The figure illustrates the predicted probability that a respondent identifies with the party, based on shifting each variable

\footnotetext{
${ }^{23}$ Put formally:$$
P_{i}=\sum_{k=1}^{m-1} \sum_{j=1}^{m} \frac{\omega_{j}+\omega_{k}}{m-1}\left|p_{j}-p_{k}\right|,
$$

where $j$ and $k$ are different parties, $p_{j}$ and $p_{k}$ are the positions the respondent assigned parties $j$ and $k, \omega_{j}$ and $\omega_{k}$ are their vote shares, and $m$ is the number of parties the respondent placed. Note that this means that only respondents who placed two or more parties are included in my analysis.

${ }^{24}$ These estimates are weighted using the design and demographic weights provided by ESEB.
} 
from its sample 25th to 75th percentile, with all other continuous variables held at their sample means and ordered variables held at their sample medians. Consistent with my expectations, the results across the Brazilian election studies suggest that individuals who perceived the parties to be further apart are indeed more likely to identify with the PT. Voters who perceive the parties to be further apart are more likely to identify with one party over another.

\section{[Figure 3 here]}

Still, these associations fail to identify the causal relationship between perceived polarization and party attachments. The ESEB surveys measure both perceived polarization and partisanship in the context of the same interview. Thus, these association may indicate the reverse causal direction, or perhaps a feedback loop between perceived polarization and partisanship.

One way to address this problem and identify the causal relationship between perceived polarization and partisanship is through repeated interviews of the same survey respondents. Indeed, part of the definition of a cause is that it occurs prior to an outcome (Finkel 1995). Panel surveys allow us to test whether perceptions of party polarization affect changes in partisanship within the same individuals over time, helping to identify the causal link (Bartels 2006). Fortunately, researchers conducted a Brazilian Election Panel Study (BEPS) in 2010 in which they asked respondents, in three interviews over the course of the election campaign, about their party attachments and their perceptions. Although perceptions about parties and voter partisanship may change slowly in more established democracies, the fragmentation and fluidity of the Brazilian party system 
offers a case where voters are likely to learn about the parties during election campaigns and shift their perceptions quite rapidly.

Compared to the ESEB, the BEPS asked slightly different questions about voter perceptions. Rather than asking about parties, the BEPS asked respondents about the positions of presidential candidates. That means that we have to assume that respondents generally perceived agreement between a party and its presidential candidate. What is useful about the BEPS questions is that they asked respondents to place the candidates on a dimension other than the ideological left-right. There are good reasons to think that different Brazilian voters understand the left-right scale differently (Zechmeister 2013), so it would be better to use a measure of voters' perception on a more politically salient dimension, like class. The BEPS asked respondents to what extent they thought the PT and PSDB presidential candidates (Dilma Roussef and José Serra, respectively), each "defends the interests of the poor" on a 0-10 scale. ${ }^{25}$ I use the difference in a respondent's placement of these candidates to measure how far apart she perceives these parties to be on the poor-rich class dimension.

To analyze the causal effect of perceived polarization on partisanship, I specify a cross-lagged structural equation model frequently used by scholars of U.S. public opinion working with panel survey data (e.g., Highton and Kam 2011; Layman and Carsey 2002; Lupu 2015b). This approach uses simultaneous equations to model current partisanship and current vote intention as functions of prior partisanship and prior vote intention. The logic behind cross-lagged causality is that a variable $X$ is said to cause another variable $Y$

\footnotetext{
${ }^{25}$ The survey question stated, "People say that some politicians defend the interest of the poor, whereas others defend the interests of the rich. I would like you to rate the following politicians from 1 to 10 on whether they defend the interests of the poor, where 1 means they don't defend the poor and 10 means they defend the poor a lot.”
} 
if prior observations of $X$ are associated with current observations of $Y$, holding constant prior observations of $Y$ (Finkel 1995: 25-6). In this context, we want to know whether prior perceived polarization affects current partisanship while taking account of preexisting partisan commitments. ${ }^{26}$ My models again control for individual demographic characteristics: household income, education, age, and gender. Since there are multiple waves in the BEPS, I pool observations of respondents in each two-wave dyad and cluster standard errors by respondent.

The results reveal a causal effect of perceived polarization on partisanship. Figure 4 reports estimates from the cross-lagged model. The left panel shows that both prior perceived partisanship and prior partisanship positively affect current partisanship. This suggests that partisanship is somewhat stable over the course of the panel (see also Lupu 2015a). But the fact that prior perceptions of polarization affect current partisanship is evidence that voters become more partisan as they perceive more polarization in Brazil.

[Figure 4 here]

I find no evidence of reverse causation in the BEPS data. The right panel in Figure 4 reports the estimated effects of prior perceptions of polarization and prior partisanship on current perceptions of polarization. Prior perceptions of polarization increase the likelihood of perceiving polarization currently, suggesting that perceptions of polarization, like partisanship, are somewhat stable over time. The concern that partisanship affects perceptions of polarization, on the other hand, finds no support. Prior

\footnotetext{
${ }^{26}$ This means simultaneously estimating the equations:

Partisanship $_{i, t}=\alpha_{1}+\beta_{1}$ Partisanship $_{i, t-1}+\gamma_{1}$ Perceivedpolarization $_{i, t-1}+\varepsilon_{1}$ Perceivedpolarization $_{i, t}=\alpha_{2}+\beta_{2}$ Partisanship $_{i, t-1}+\gamma_{2}$ Perceivedpolarization $_{i, t-1}+\varepsilon_{2}$
} 
partisanship does not have a statistically significant effect on current perceptions of polarization.

Survey data for Brazil thus confirms my individual-level expectations. In both Argentina and Brazil, aggregate trends in partisanship and party polarization correlated by and large as I hypothesized. But these aggregate trends could be misleading about the individual-level relationships or the direction of causality. If distinguishable party brands are a necessary condition for partisanship at the level of individual voters, then we should be able to uncover such a relationship with appropriate survey data. Indeed, national surveys from Brazil show just such a relationship, and allow us to identify the causal effect of perceiving party differences on partisanship.

\section{Party Brands, Timing, and the Success of New Parties}

New political parties regularly come and go in multiparty systems. But some succeed in becoming major competitors in national elections. To achieve that level of success, new parties must build a broad partisan base that cushions the party against rapid shifts in public opinion. Because partisans give their party the benefit of the doubt, successful mass parties need to build a base of partisans to rely on in unfavorable times.

Building a broad base of partisans requires an appealing, consistent, and differentiable party brand. Parties must stake out a position that signals that they represent a large swath of the electorate, and they must send that signal consistently to voters. If voters observe mixed signals from the party and its leaders, they will see an ambiguous brand and fail to form strong attachments. In addition, strong party brands require that parties differentiate themselves from their competitors. If voters see 
negligible differences between the parties, they are unlikely to form lasting attachments to one over the other. Instead, when voters unambiguously perceive a party that represents citizens like them, in stark contrast to its rivals, they are far more likely to identify with it.

Argentina's FREPASO and Brazil’s PT both succeeded in building such a brand. In the mid-1990s, FREPASO adopted a consistent and prominent center-left stance in opposition to the social costs of Menem's neoliberal economic reforms. At a time when Menem's PJ and its traditional rival, the UCR, had converged on the reform agenda, FREPASO became a credible alternative. The PT pursued a similar tack. Eschewing the radical leftwing platform of its origins, the party shifted to the center-left just as Cardoso's PSDB implemented its neoliberal program. Appealing to a broader swath of Brazilians, the PT, like FREPASO, led the national center-left opposition at a time when the social costs of the Washington Consensus were being felt by millions of voters. Indeed, those Brazilians who saw more differences between the parties were most likely to identify with the PT. Despite the vast differences between the Argentine and Brazilian party systems, these new parties developed strong brands and built growing bases of partisan support. Comparing their successes shows that broad, consistent, and differentiated party brands help parties attract mass attachments.

The comparison on FREPASO and the PT also suggests that, at least during the 1990s heyday of the Washington Consensus, new left parties did better when they remained out of office than when they won elections (see also Roberts 2015, this volume). New left parties could stake out clear brands on the ideological left as long as they were not required to govern. Once in office, however, they confronted economic 
constraints that forced them into compromising those positions and eroding their partisan base (Lupu 2014, Forthcoming), as the case of FREPASO demonstrates. Had FREPASO not pragmatically allied itself with the UCR, it would likely have remained in opposition for some time, strengthening its brand and expanding its partisan base. Instead, FREPASO entered a coalition government whose policies increasingly contradicted its brand, eroding the party’s fledgling base.

By the time the PT won the presidency, in contrast, the Washington Consensus had waned and rising commodity prices provided leeway for leftist administrations to abandon neoliberal prescriptions (see Levitsky and Roberts 2011). That allowed the PT to maintain its center-left position on redistribution and social programs without sacrificing macroeconomic stability. The PT had gradually abandoned aspects of its more radical early brand, but it did so with abandoning its entire platform, as FREPASO did. The PT’s inconsistency also brought it closer to mainstream Brazilian voters, increasing its potential appeal. It seems one crucial reason for the PT's success in building a partisan following was its repeated national electoral defeats; had Lula won the presidency in 1989, his party’s fate would likely have looked more like FREPASO’s. 


\section{References}

Abal Medina, Juan. 2009. "The Rise and Fall of the Argentine Center-Left: The Crisis of Frente Grande.” Party Politics 15 (3): 357-375.

Achen, Christopher H. 1992. "Social Psychology, Demographic Variables, and Linear Regression: Breaking the Iron Triangle in Voting Research.” Political Behavior 14 (3): 195-211.

Albright, Jeremy J. 2009. “Does political knowledge erode party attachments? A review of the cognitive mobilization thesis.” Electoral Studies 28 (2): 248-260.

Álvarez, Chacho, and Joaquín Morales Solá. 2002. Sin excusas. Buenos Aires: Editorial Sudamericana.

Amaral, Oswaldo. 2011. “Ainda conectado: o PT e seus vínculos com a sociedade.” Opinião Pública 17 (1): 1-44.

Arzheimer, Kai. 2006. "Dead men walking? Party identification in Germany, 19772002.” Electoral Studies 25 (4): 791-807.

Bartels, Larry M. 2000. “Partisanship and Voting Behavior, 1952-1996.” American Journal of Political Science 44 (1): 35-50.

Bartels, Larry M. 2006. “Three Virtues of Panel Data for the Analysis of Campaign Effects.” In Capturing Campaign Effects, edited by Henry E. Brady and Richard Johnston. Ann Arbor: University of Michigan Press.

Bartle, John, and Paolo Bellucci. 2009. Political parties and partisanship: Social identity and individual attitudes. New York: Routledge.

Baumer, Donald C., and Howard J. Gold. 1995. "Party Images and the American Electorate.” American Politics Research 23 (1): 33-61.

Berglund, Frode, Sören Holmberg, Hermann Schmitt, and Jacques Thomassen. 2006. "Party Identification and Party Choice." In The European Voter, edited by Jacques Thomassen. Oxford: Oxford University Press.

Brader, Ted, and Joshua A. Tucker. 2008. "Reflective and Unreflective Partisans? Experimental Evidence on the Links between Information, Opinion, and Party Identification.” Unpublished manuscript.

Budge, Ian, Ivor Crewe, and Dennis Farlie. 1976. Party Identification and Beyond: Representations of Voting and Party Competition. New York: John Wiley \& Sons.

Calvo, Ernesto, and Marcelo Escolar. 2005. La nueva política de partidos en la Argentina: Crisis política, realineamientos políticos y reforma electoral. Buenos Aires: Prometeo. 
Campbell, Angus, Philip E. Converse, Warren E. Miller, and Donald E. Stokes. 1960. The American Voter. New York: John Wiley \& Sons.

Campello, Daniela. 2015. Globalization and Democracy: The Politics of Market Discipline in Latin America. Cambridge: Cambridge University Press.

Cheresky, Isidoro. 2003. "Las elecciones nacionales de 1999 y 2001: Fluctuación del voto, debilitamiento de la cohesión partidaria y crisis de representación.” In De la ilusión reformista al descontento ciudadano: Las elecciones en Argentina, 19992001, edited by Isidoro Cheresky and Jean-Michel Blanquer. Buenos Aires: Homo Sapiens Ediciones.

Converse, Philip E. 1969. “Of Time and Partisan Stability.” Comparative Political Studies 2 (2): 139-71.

Dalton, Russell J. 1984. "Cognitive Mobilization and Partisan Dealignment in Advanced Industrial Democracies.” Journal of Politics 46 (1): 264-284.

Delli Carpini, Michael X., and Scott Keeter. 1996. What Americans Know About Politics and Why It Matters. New Haven: Yale University Press.

Fernandes Veiga, Luciana. 2011. “O partidarismo no Brasil (2002/2010).” Opinião Pública 17 (2): 400-25.

Finkel, Steven E. 1995. Causal Analysis with Panel Data. Thousand Oaks, CA: Sage Publications.

Fiorina, Morris P. 1981. Retrospective Voting in American National Elections. New Haven: Yale University Press.

Flanagan, Scott C., and Russell J. Dalton. 1984. "Parties under stress: Realignment and dealignment in advanced industrial societies.” West European Politics 7 (1): 7-23.

García Lema, Alberto. 1994. La reforma por dentro: la difícil construcción del consenso constitucional. Buenos Aires: Planeta.

Gerchunoff, Pablo, and Juan Carlos Torre. 1996. "La política de liberalización económica en la administración de Menem.” Desarrollo Económico 36 (143): 733-768.

Green, Donald Philip, Bradley Palmquist, and Eric Schickler. 2002. Partisan Hearts and Minds: Political Parties and the Social Identities of Voters. New Haven: Yale University Press.

Grindle, Merilee S. 2000. Audacious Reforms: Institutional Invention and Democracy in Latin America. Baltimore: The Johns Hopkins University Press.

Grynaviski, Jeffrey D. 2010. Partisan Bonds: Political Reputations and Legislative Accountability. Cambridge: Cambridge University Press. 
Hagopian, Frances, Carlos Gervasoni, and Juan Andres Moraes. 2009. "From Patronage to Program: The Emergence of Party-Oriented Legislators in Brazil.” Comparative Political Studies 42 (3): 360-391.

Hetherington, Marc J. 2001. "Resurgent Mass Partisanship: The Role of Elite Polarization.” American Political Science Review 95 (3): 619-631.

Highton, Benjamin, and Cindy D. Kam. 2011. "The Long-Term Dynamics of Partisanship and Issue Orientations.” Journal of Politics 73 (1): 202-215.

Hirschman, Albert O. 1970. Exit, Voice, and Loyalty: Responses to Decline in Firms, Organizations, and States. Cambridge, MA: Harvard University Press.

Hogg, Michael A., Dominic Abrams, Sabine Otten, and Steve Hinkle. 2004. "The Social Identity Perspective: Intergroup Relations, Self-Conception, and Small Groups.” Small Group Research 35 (3): 246-276.

Huber, John D., Georgia Kernell, and Eduardo L. Leoni. 2005. “Institutional Context, Cognitive Resources and Party Attachments Across Democracies.” Political Analysis 13 (4): 365-386.

Hunter, Wendy. 2010. The Transformation of the Workers' Party in Brazil, 1989-2009. Cambridge: Cambridge University Press.

Hunter, Wendy, and Timothy J. Power. 2007. "Rewarding Lula: Executive Power, Social Power, and the Brazilian Elections of 2006." Latin American Politics and Society 49 (1): 1-30.

Inglehart, Ronald. 1977. The Silent Revolution: Changing Values and Political Styles Among Western Publics. Princeton: Princeton University Press.

Jones, Mark P. 1996. “Assessing the Public’s Understanding of Constitutional Reform: Evidence from Argentina.” Political Behavior 18 (1): 25-49.

Jones, Mark P., and Wonjae Hwang. 2005. "Provincial Party Bosses: Keystone of the Argentine Congress.” In Argentine Democracy: The Politics of Institutional Weakness, edited by Steven Levitsky and Mara Victoria Murillo. University Park, PA: Pennsylvania State University Press.

Katz, Richard S., and Peter Mair. 1995. "Changing Models of Party Organization and Party Democracy: The Emergence of the Cartel Party.” Party Politics 1 (1): 5-28.

Kayser, Mark Andreas, and Christopher Wlezien. 2011. "Performance pressure: Patterns of partisanship and the economic vote.” European Journal of Political Research 50 (3): 365-394.

Keck, Margaret E. 1992. The Worker's Party and Democratization in Brazil. New Haven: Yale University Press. 
Kirchheimer, Otto. 1966. "The Transformation of the Western European Party Systems.” In Political Parties and Political Development, edited by Joseph LaPalombara and Myron Weiner, 177-200. Princeton: Princeton University Press.

Layman, Geoffrey C., and Thomas M. Carsey. 2002. "Party Polarization and Party Structuring of Policy Attitudes: A Comparison of Three NES Panel Studies.” Political Behavior 24 (3): 199-236.

LeBas, Adrienne. 2011. From Protest to Parties: Party-Building and Democratization in Africa. Oxford: Oxford University Press.

Levitsky, Steven. 2003. Transforming Labor-Based Parties in Latin America: Argentine Peronism in Comparative Perspective. Cambridge: Cambridge University Press.

Levitsky, Steven, and María Victoria Murillo. 2003. “Argentina Weathers the Storm.” Journal of Democracy 14 (4): 152-66.

Levitsky, Steven, and Kenneth M. Roberts, eds. 2011. The Resurgence of the Latin American Left. Baltimore: The Johns Hopkins University Press.

Lupu, Noam. 2013. "Party Brands and Partisanship: Theory with Evidence from a Survey Experiment in Argentina.” American Journal of Political Science 57 (1): 49-64.

Lupu, Noam. 2014. "Brand Dilution and the Breakdown of Political Parties in Latin America.” World Politics 66 (4): 561-602.

Lupu, Noam. 2015a. "Partisanship in Latin America.” In The Latin American Voter: Pursuing Representation and Accountability in Challenging Contexts, edited by Ryan E. Carlin, Matthew M. Singer and Elizabeth J. Zechmeister, 226-245. Ann Arbor: University of Michigan Press.

Lupu, Noam. 2015b. "Party Polarization and Mass Partisanship: A Comparative Perspective.” Political Behavior 37 (2): 331--356.

Lupu, Noam. Forthcoming. Party Brands in Crisis: Partisanship, Brand Dilution, and the Breakdown of Political Parties in Latin America. Cambridge: Cambridge University Press.

Lupu, Noam, and Susan C. Stokes. 2009. "The Social Bases of Political Parties in Argentina, 1912-2003.” Latin American Research Review 44 (1): 58-87.

Lyne, Mona M. 2005. "Parties as Programmatic Agents: A Test of Institutional Theory in Brazil.” Party Politics 11 (2): 193-216.

Mainwaring, Scott. 1999. Rethinking Party Systems in the Third Wave of Democratization: The Case of Brazil. Stanford, CA: Stanford University Press. 
Mainwaring, Scott, and Timothy R. Scully. 1995. "Introduction: Party Systems in Latin America.” In Building Democratic Institutions: Party Systems in Latin America, edited by Scott Mainwaring and Timothy R. Scully. Stanford, CA: Stanford University Press.

McGuire, James W. 1997. Peronism without Perón: Unions, Parties, and Democracy in Argentina. Stanford, CA: Stanford University Press.

Melo, Carlos Ranulfo, and Rafael Câmara. 2012. "Estrutura da Competição pela Presidência e Consolidação do Sistema Partidário no Brasil.” Dados 55 (1): 71117.

Meneguello, Rachel. 1989. PT: A formação de um partido, 1979-1982. São Paulo: Paz e Terra.

Mora y Araujo, Manuel. 1995. “De Perón a Menem: Una historia del peronismo.” In Peronismo y menemismo: Avatares del populismo en la Argentina. Buenos Aires: Ediciones El Cielo por Asalto.

Morgan, Jana. 2011. Bankrupt Representation and Party System Collapse. University Park, PA: Pennsylvania State University Press.

Mustapic, Ana María. 2005. “Inestabilidad sin colapso: La renuncia de los presidentes: Argentina en el año 2001.” Desarrollo Económico 45 (178): 263-280.

Negretto, Gabriel. 2001. "Negociando los poderes del presidente: reforma y cambio constitucional en la Argentina.” Desarrollo Económico 41 (163): 411-444.

Novaro, Marcos. 2009. Argentina en el fin de siglo: Democracia, mercado y Nación (1983-2001). Buenos Aires: Paidós.

Novaro, Marcos, and Vicente Palermo. 1998. Los caminos de la centroizquierda: Dilemas y desafíos del Frepaso y de la Alianza. Buenos Aires: Editorial Losada.

Power, Timothy J. 1998. "Brazilian Politicians and Neoliberalism: Mapping Support for the Cardoso Reforms, 1995-1997.” Journal of Interamerican Studies and World Affairs 40 (4): 51-72.

Power, Timothy J. 2008. "Centering Democracy? Ideological Cleavages and Convergence in the Brazilian Political Class.” In Democratic Brazil Revisited, edited by Peter R. Kingstone and Timothy J. Power, 81-106. Pittsburgh, PA: University of Pittsburgh Press.

Power, Timothy, and Cesar Zucco. 2009. "Estimating Ideology of Brazilian Legislative Parties, 1990-2005: A Research Communication,” Latin American Research Review 44 (1): 218-46. 
Przeworski, Adam, and John Sprague. 1986. Paper Stones: A History of Electoral Socialism. Chicago: The University of Chicago Press.

Rahn, Wendy M. 1993. "The Role of Partisan Stereotypes in Information Processing about Political Candidates.” American Journal of Political Science 37 (2): 472496.

Ribeiro, Pedro Floriano. 2014. "An Amphibian Party? Organisational Change and Adaptation in the Brazilian Workers’ Party, 1980-2012.” Journal of Latin American Studies 46 (1): 87-119.

Roberts, Kenneth M. 2015. Changing Course: Parties, Populism, and Political Representation in Latin America's Neoliberal Era. Cambridge: Cambridge University Press.

Roma, Celso. 2002. “A institucionalização do PSDB entre 1988 e 1999.” Revista Brasileira de Ciências Sociais 17 (49): 71-92.

Roma, Celso. 2006. "Organizaciones de partido en Brasil: El PT y el PSDB bajo perspectiva comparada.” América Latina Hoy 44 153-84.

Samuels, David. 1999. "Incentives to Cultivate a Party Vote in Candidate-Centric Electoral Systems: Evidence from Brazil.” Comparative Political Studies 32 (4): 487-518.

Samuels, David. 2004. "From Socialism to Social Democracy: Party Organization and the Transformation of the Workers' Party in Brazil." Comparative Political Studies 37 (9): 999-1024.

Samuels, David. 2006. "Sources of Mass Partisanship in Brazil.” Latin American Politics and Society 48 (2): 1-27.

Samuels, David. 2008. "Brazil: Democracy under Lula and the PT.” In Constructing Democratic Governance in Latin America, eds. Jorge I. Domínguez and Michael Shifter, 3rd ed. Baltimore: The Johns Hopkins University Press. 152-76.

Samuels, David, and Cesar Zucco. 2010. "The Roots of Petismo, 1989-2010.” Unpublished manuscript.

Samuels, David, and Cesar Zucco. 2014. "The Power of Partisanship in Brazil: Evidence from Survey Experiments.” American Journal of Political Science 58 (1): 212-25.

Samuels, David, and Cesar Zucco. Forthcoming. "Crafting Mass Partisanship at the Grass Roots.” British Journal of Political Science.

Sanders, Arthur. 1988. “The Meaning of Party Images.” Political Research Quarterly 41: 583-599. 
Schmitt-Beck, Rüdiger, Stefan Weick, and Bernhard Christoph. 2006. "Shaky attachments: Individual-level stability and change of partisanship among West German voters, 1984-2001.” European Journal of Political Research 45 (4): 581608.

Schmitt, Hermann, and Sören Holmberg. 1995. "Political Parties in Decline?” In Citizens and the State, edited by Hans-Dieter Klingemann and Dieter Fuchs. Oxford: Oxford University Press.

Seawright, Jason. 2012. Party-System Collapse: The Roots of Crisis in Peru and Venezuela. Stanford, CA: Stanford University Press.

Sousa Braga, María do Socorro, and Jairo Pimentel, Jr. 2011. “Os partidos políticos brasileiros realmente não importam?” Opinião Pública 17 (2): 271-303.

Stokes, Susan C. 2001. Mandates and Democracy: Neoliberalism by Surprise in Latin America. Cambridge: Cambridge University Press.

Thomassen, Jacques. 1976. "Party Identification as a Cross-National Concept: Its Meaning in the Netherlands.” In Party Identification and Beyond: Representations of Voting and Party Competition, edited by Ian Budge, Ivor Crewe, and Dennis Farlie. New York: John Wiley \& Sons.

Turner, John C. 1999. “Some Current Issues in Research on Social Identity and SelfCategorization Theories.” In Social Identity: Context, Commitment, Content, edited by Naomi Ellemers, Russell Spears, and Bertjan Doosje. Malden, MA: Blackwell.

Turner, John C., Michael A. Hogg, Penelope Oakes, Stephen Reicher, and Margaret Wetherell. 1987. Rediscovering the Social Group: A Self-Categorization Theory. New York: Blackwell.

Van Dyck, Brandon. 2014. “Why Party Organization Still Matters: The Workers’ Party in Northeastern Brazil.” Latin American Politics and Society 56 (2): 1-26.

Ward, Ian. 1993. “'Media Intrusion' and the Changing Nature of the Established Parties in Australia and Canada.” Canadian Journal of Political Science 26 (3): 477-506.

Zechmeister, Elizabeth. 2013. “Ideology.” In The Latin American Voter, eds. Ryan E. Carlin, Matthew M. Singer and Elizabeth Zechmeister.

Zucco, Cesar. 2008. “The President's 'New' Constituency: Lula and the Pragmatic Vote in Brazil’s 2006 Presidential Election.” Journal of Latin American Studies 40 (1): 19-49.

Zucco, Cesar, Jr., and Benjamin E. Lauderdale. 2011. “Distinguishing Between Influences on Brazilian Legislative Behavior.” Legislative Studies Quarterly 36 (3): 363-96. 
Figure 1. FREPASO partisanship in Argentina, 1994-2003

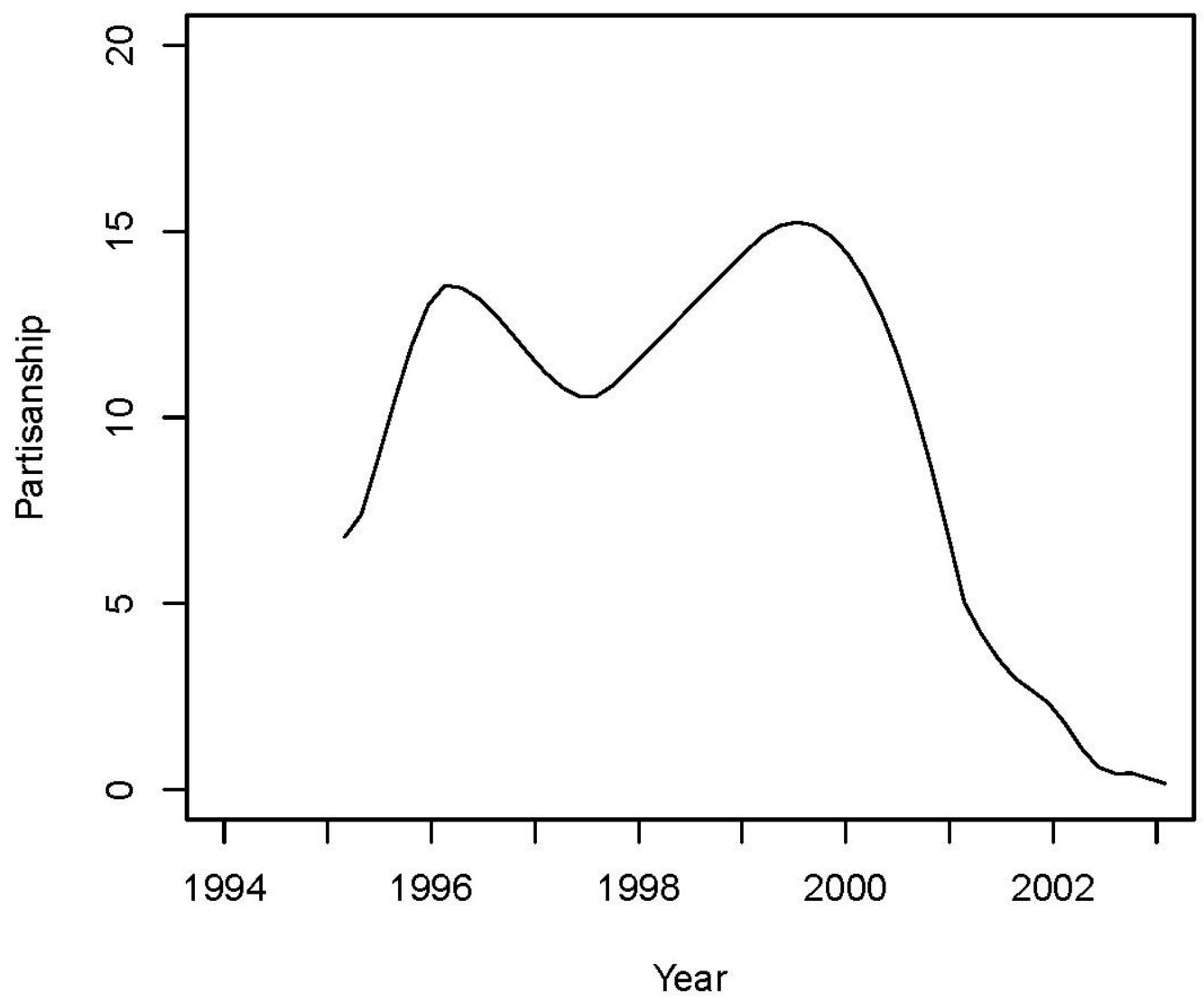

Notes: Lines represent proportions of respondents from 19 surveys who said they identified with FREPASO. These are moving averages generated by locally weighted (loess) regressions ( $\alpha=0.3, \lambda=1$ ). Sources: Carlos Fara \& Associates; Gallup International; Mansilla, Delich, \& Associates; Romer \& Associates; Sofres-Ibope 
Figure 2. PT partisanship in Brazil, 1989-2011

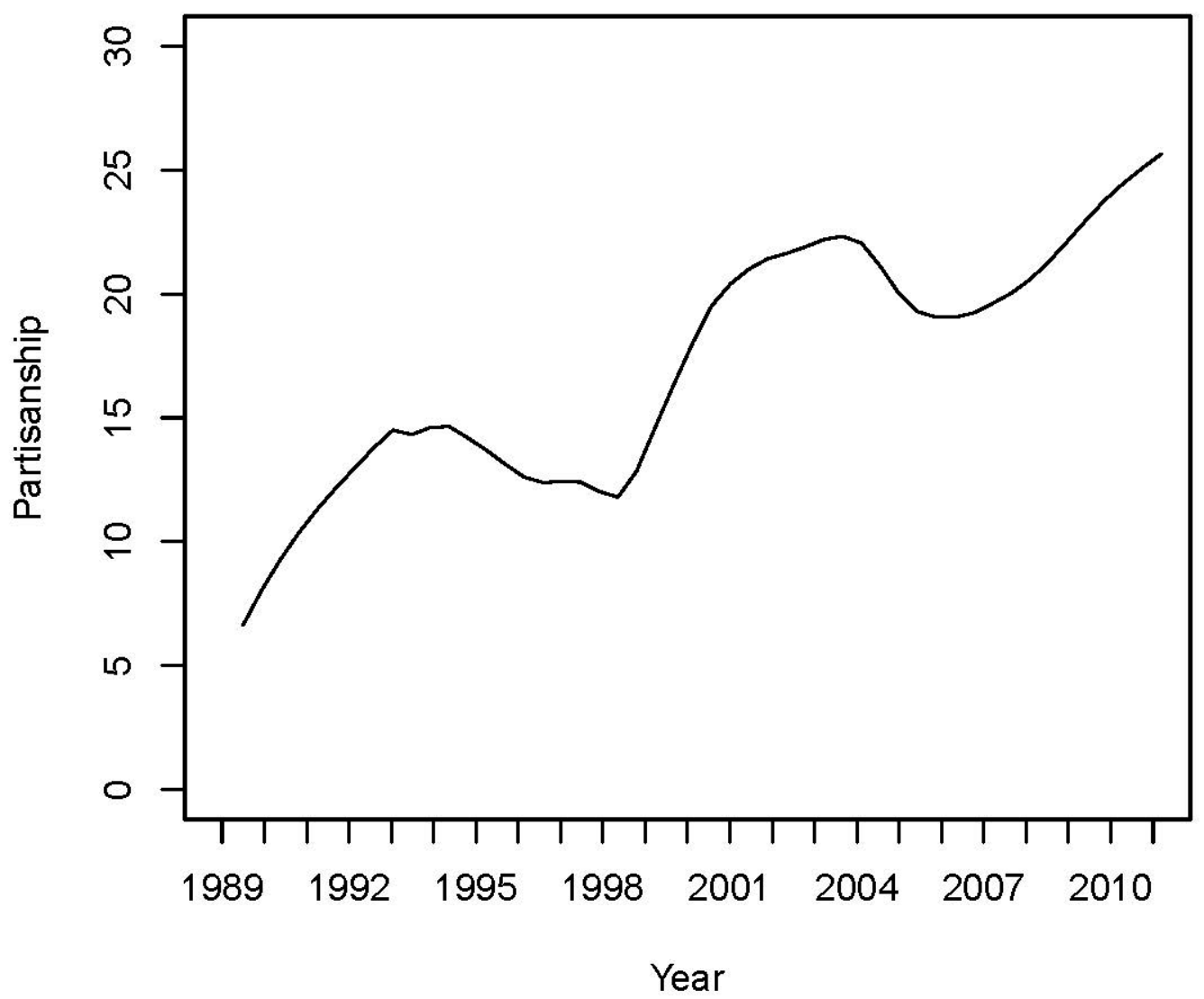

Notes: Lines represent proportions of respondents from 75 national surveys who said they identified with the PT. These are moving averages generated by locally weighted (loess) regressions $(\alpha=0.2, \lambda=2)$. Source: Datafolha 
Figure 3. Perceived polarization and PT partisanship in Brazil

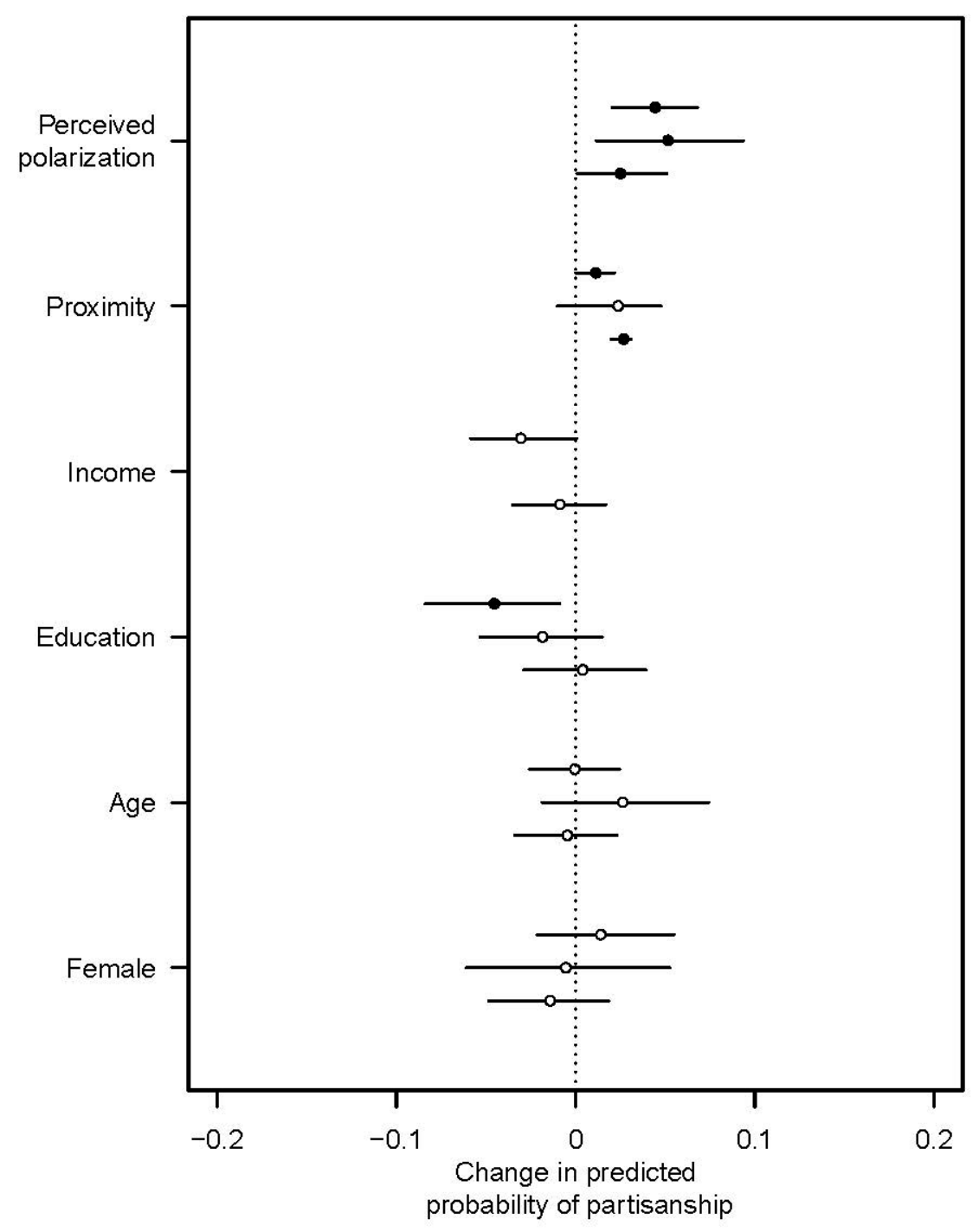

Notes: Values represent changes in the predicted probability that a respondent identifies with the PT, based on shifting each variable from its sample $25^{\text {th }}$ to $75^{\text {th }}$ percentile, with all other continuous variables held at their sample means and ordered variables held at their sample medians. Solid lines show the simulated 95\% confidence interval. Black dots represent values that are significant at 95\% confidence, white dots those that fall short of that threshold. For each variable, the top value represents the result from the 2002 survey, the middle value the 2006 survey, and the bottom value the 2010 survey. These predicted values are based on the estimates from probit models presented in Appendix Table A1 (2002: $N=1,512, R^{2}=0.024$; 2006: $N=484, R^{2}=0.024 ; 2010: N=1,026, R^{2}=0.026$ ).

Source: ESEB 2002, 2006, 2010 
Figure 4. Perceived polarization and PT partisanship in Brazil, panel survey

Partisanship

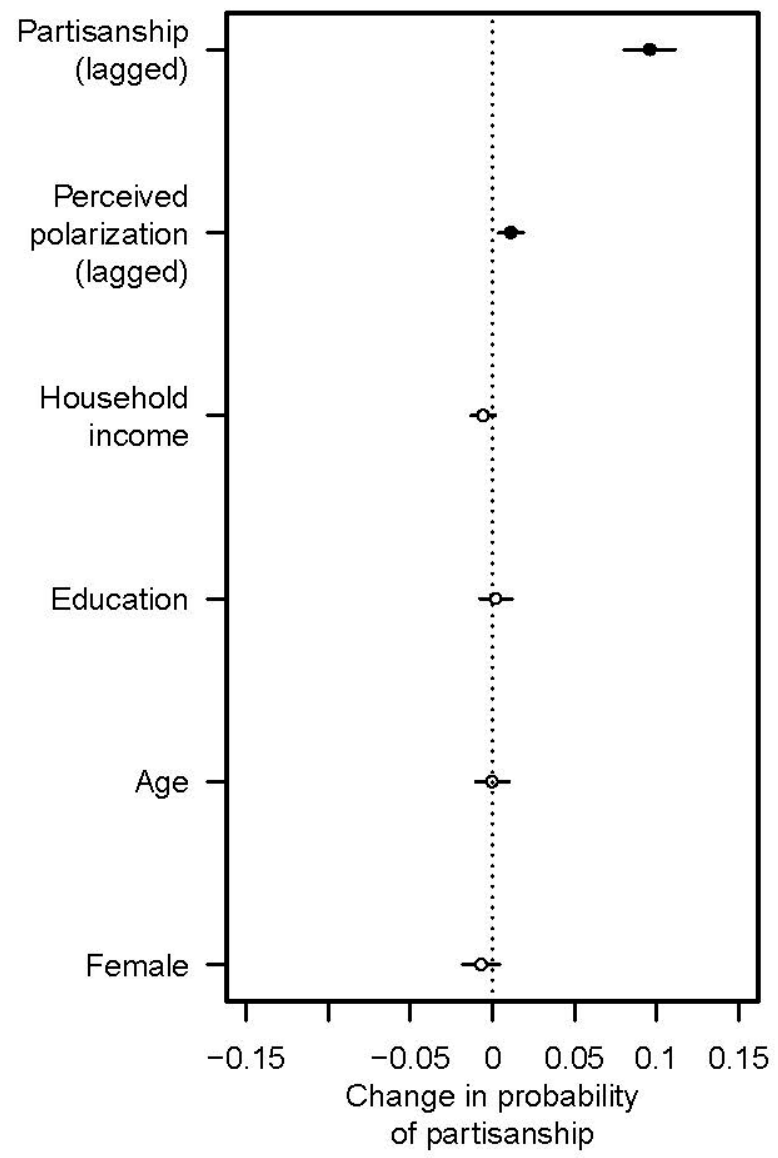

Perceived polarization

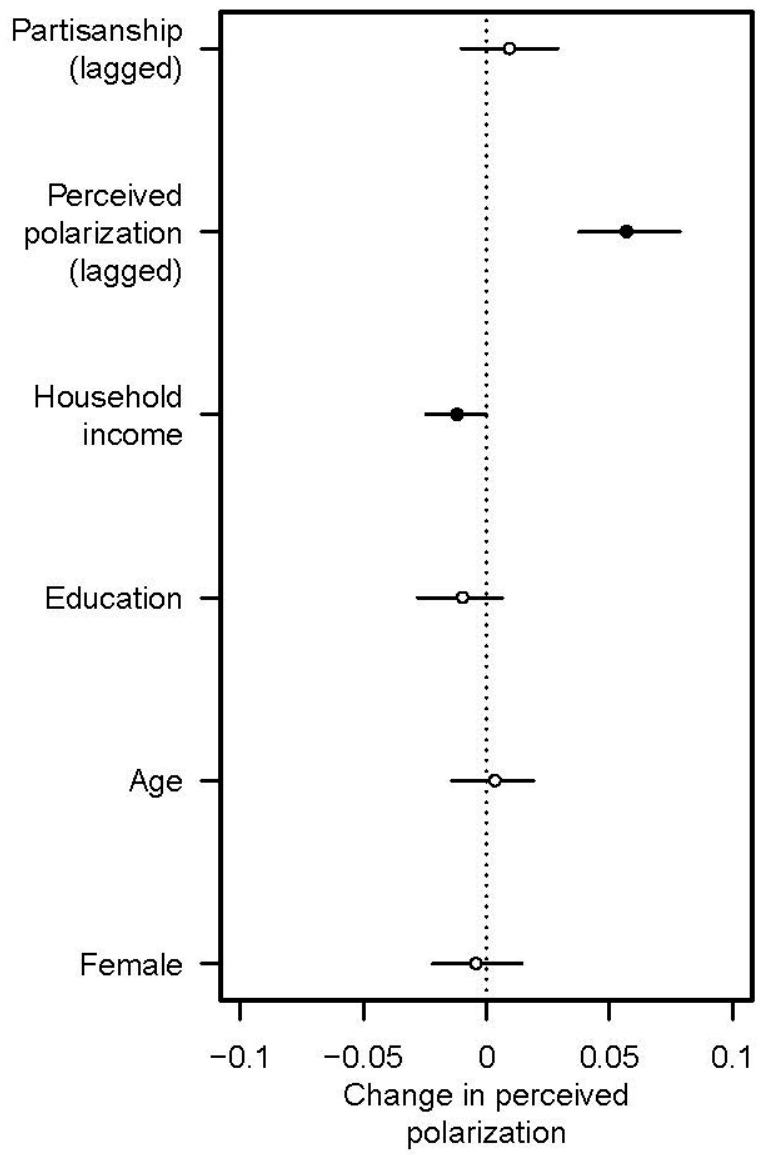

Notes: Values represent changes in the predicted probability that a respondent identifies with the PT or perceives polarization between the parties, based on shifting each variable from its sample $25^{\text {th }}$ to $75^{\text {th }}$ percentile, with all other continuous variables held at their sample means and ordered variables held at their sample medians. Solid lines show the simulated 95\% confidence interval. Black dots represent values that are significant at $95 \%$ confidence, white dots those that fall short of that threshold. These predicted values are based on cross-lagged structural equation estimates presented in Appendix Table A2 $(\mathrm{N}=1,208)$.

Source: BEPS 2010 


\section{Appendix}

Table A1. Perceived polarization and PT partisanship in Brazil

\begin{tabular}{lccc} 
& $\mathbf{2 0 0 2}$ & $\mathbf{2 0 0 6}$ & $\mathbf{2 0 1 0}$ \\
\hline Perceived polarization & $0.129 * *$ & $0.149^{*}$ & $0.084^{*}$ \\
& $(0.037)$ & $(0.060)$ & $(0.043)$ \\
Proximity & 0.047 & 0.057 & $0.142^{* *}$ \\
& $(0.025)$ & $(0.039)$ & $(0.029)$ \\
Household income & $-0.062^{*}$ & & -0.020 \\
& $(0.031)$ & & $(0.033)$ \\
Education & $-0.091^{*}$ & -0.081 & 0.010 \\
Age & $(0.039)$ & $(0.076)$ & $(0.042)$ \\
& -0.000 & 0.005 & -0.001 \\
Female & $(0.003)$ & $(0.005)$ & $(0.003)$ \\
& 0.057 & -0.028 & -0.070 \\
Constant & $(0.076)$ & $(0.131)$ & $(0.081)$ \\
& -0.129 & -0.885 & $-1.137 * *$ \\
Observations & $(0.270)$ & $(0.511)$ & $(0.344)$ \\
Pseudo-R2 & 1,512 & 484 & 1,026 \\
ePCP & 0.024 & 0.024 & 0.026 \\
\hline \hline
\end{tabular}

Notes: Robust standard errors in parentheses; ${ }^{* *} p<0.01,{ }^{*} p<0.05$. Source: ESEB 


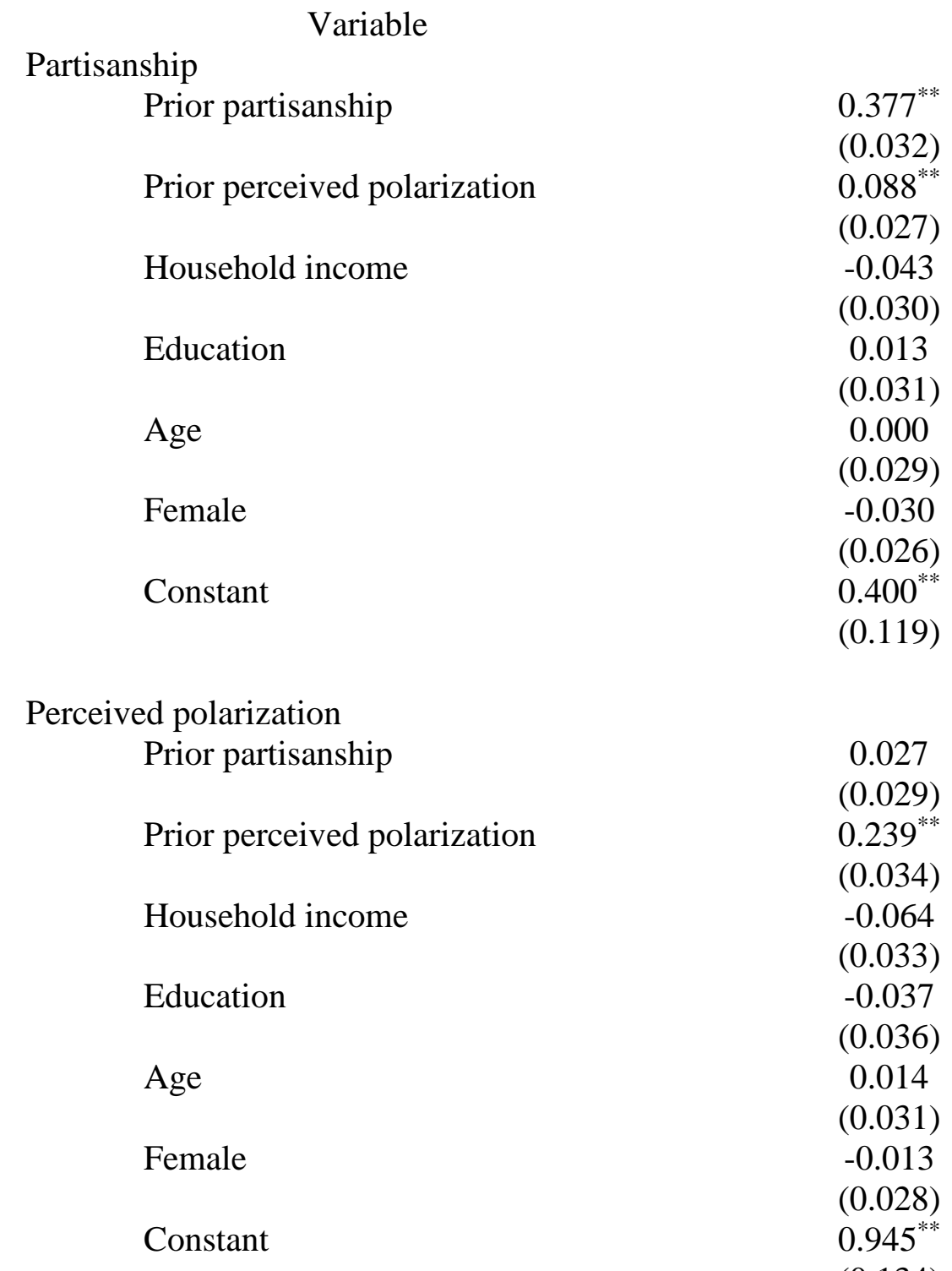

\footnotetext{
Observations $\quad 1,208$

Respondents $\quad 815$

Log-likelihood $\quad-18360.69$

Notes: Clustered standard errors in parentheses; $* * p<0.01,{ }^{*} p<0.05$.

Source: BEPS 2010
} 